\title{
Improving Community-Based Conservation Near Protected Areas: The Importance of Development Variables
}

PETER J. BALINT*

Department of Public and International Affairs

George Mason University

4400 University Drive, MSN 3F4

Fairfax, VA 22030, USA

ABSTRACT / Community-based conservation projects implemented in conjunction with protected area management often struggle to meet expectations. This article argues that outcomes will improve if project leaders pay closer attention to four development indicators_rights, capacity, governance, and revenue - that are often taken for granted or considered beyond the scope of local conservation projects. I make the case for focusing on these variables in four steps. First, I distinguish community-based conservation linked to protected area management from community-based institutions studied by scholars of the commons. Second, I draw on the theory and practice of international development to highlight the central relevance of the variables highlighted in this article to development projects at all levels. Third, I discuss the four variables in some detail, considering problems of definition and measurement and reviewing possible interactions among them. Fourth, to illustrate the influence of the variables in particular cases, I review outcomes from community-based conservation projects implemented near protected areas in El Salvador and Zimbabwe.
For impoverished human communities in rural areas of the developing world, there are often significant costs associated with living along the border of a national park or other nature reserves. These costs include loss of access to traditional resources; reduced social, political, and environmental autonomy; and increased threats to life and property from wild animals migrating in and out of the nearby protected area (Geisler 2002; Packer and others 2005). Conversely, those concerned with protected area management, including government officials, park administrators,

1 donors, and nongovernment organization (NGO) staff, often confront substantial problems associated with the presence of nearby villages (Brandon and others 1998; Hockings 2003). These problems include direct effects from unauthorized use of park resources and indirect effects from upstream land-use practices that generate erosion and siltation, habitat fragmentation, and so on. Not surprisingly, the costs that each side imposes on the other foster conflicts. Villagers commonly act to

KEY WORDS: Community-based conservation; Protected areas; Rights; Capacity; Governance; El Salvador; Zimbabwe

Published online

*Author to whom correspondence should be addressed; email: pbalint@gmu.edu circumvent regulations out of necessity or in response to perceived injustice, and park managers often respond with increased enforcement efforts against local people whose activities they see as undermining conservation objectives (Neumann 2004).

The idea of community-based conservation (CBC) grew in part out of attempts to address these conflicts by generating mutual benefits to reduce or offset costs incurred on both sides (Western and Wright 1994). CBC has many variants and has been applied in a wide range of circumstances relating to natural resource management [see Roe and Jack (2001) for a review and typology], but in this article I focus specifically on CBC applied as a tool for addressing conflicts between resource management agencies and local communities along the perimeters of protected areas (PAs). In this article, I use the acronym CBC-PA when referring to this type of intervention.

The common element of such projects is an effort to change the incentive structure both for PA management institutions, including government agencies and the donors and NGOs that support them, and for local communities (Hulme and Murphree 2001; Li 2002). CBC-PA projects typically involve sharing park revenue with local residents, promoting opportunities for villagers to earn income from tourism, or offering other social and economic improvements linked to conservation. In theory, park managers have incentives to 
develop and strengthen such projects in order to reduce levels of encroachment and conflict, and villagers then have incentives to support rather than undermine PA management regimes in order to maintain the flow of benefits.

Yet despite powerful logic favoring the approach, CBC-PA projects in practice often fail to meet expectations related either to park protection or to community development (Brown 2002; Songorwa 1999; Twyman 2000). Problems of prioritization and emphasis between the dual objectives can contribute to the disappointing results. Although CBC-PA projects are implemented with the primary purpose of promoting conservation in and near PAs, the problems that undermine success often reflect difficulties experienced in international development more broadly. Thus, I argue in this article that practitioners and researchers involved in working to improve outcomes in CBC-PA need also to address factors that have been identified as critical to the success of development initiatives. In particular, I focus on rights, capacity, governance, and revenue. These variables are likely to be critical predictors of success in CBC-PA even though they are often judged to be beyond the scope of local conservation efforts.

The article proceeds as follows. The first section delimits the topic by distinguishing the type of CBC projects discussed in this article from community-based natural resource management institutions studied by scholars of the commons. The second section justifies a focus on rights, capacity, governance, and revenue based on current theory and practice of international development. The third section considers the four variables in some detail, examining problems of definition and measurement and reviewing likely correlations and interactions among them. The fourth section presents empirical evidence for the importance of the variables by reviewing case studies of three relevant projects: two near El Imposible National Park in El Salvador and one near Gonarezhou National Park in Zimbabwe.

\section{Distinguishing CBC-PA from Other "Community-Based" Institutions}

This section makes the case that, despite nominal similarities related to the use of the term "community based," CBC-PA projects are substantially different from the self-organized institutions studied by scholars of the commons (Ostrom and others 2002). Given these differences, I argue that findings from commons scholarship regarding factors correlated with success in community-based natural resource management do not fully account for the specific characteristics of CBC-PA, thereby opening the way for discussion of the alternate set of explanatory variables highlighted in this article.

In the literature on managing the commons, the term "community based" refers to cases in which environmental governance practices have evolved at the community level to manage common-pool resources sustainably and thus avoid Hardin's (1968) "tragedy of the commons" (Ostrom 1990; Stern and others 2002). These emergent, self-organized collective actions have deep social, political, and historical roots and depend on long-running negotiations, compromises, and collaborations among various parties, each with some separate power and standing. Stern and others (2002, p. 456) included among the defining characteristics of such collective action that resource users have "the autonomy to devise and change rules" and "the opportunity to bargain." Scholars of the commons distinguish these governance practices from two other means of avoiding overexploitation of common-pool resources: private ownership and state ownership (Dietz and others 2002).

In cases in which CBC-PA projects are implemented, however, the government has already asserted authority over the resources in question by formally gazetting the protected area-often at the same time promulgating restrictions in the buffer zone where human communities are located. Villagers typically have minimal autonomy for devising and changing rules and have, at best, severely limited bargaining power with implementing agencies. In the context of CBC-PA, the term "community based" refers to situations in which resource management agencies promote projects in the communities, rather than to situations in which local residents apply their own norms and institutions, either independently or in cooperation with other stakeholders. Indeed, the establishment of the stateowned reserve and the enforcement of associated regulations often supersede preexisting indigenous communal resource management regimes in what has become the PA. Although villagers might continue to manage their remaining holdings outside of the PA in common through application of community norms and institutions, these practices are distinct from-and often in conflict with-the externally directed CBC-PA projects (Neumann 1998).

Consequently, although researchers have identified sets of variables that might influence the emergence and effectiveness of commons management institutions-including characteristics of the common-pool resources, characteristics of the users, decision-making processes and management practices in effect, behaviors of external actors, and interactions at various levels 
among these sets of variables (Agrawal 2001; Baland and Platteau 1996; Ostrom 1990; Wade 1988)—-these do not fully address the narrower case of CBC-PA. In the following sections, I discuss an alternate set of variables that are more directly relevant.

\section{Variables Deserving Attention in CBC-PA Projects}

CBC-PA projects are implemented with the purpose of strengthening conservation efforts in and around PAs. To contribute to long-term conservation goals, however, these projects must improve local livelihoods in the near term and thereby reduce levels of encroachment and conflict. Community development is valuable in its own right, and for reasons of fairness and justice, it might be of particular salience in areas where already poor communities suffer as a result of the proximity of nature reserves. Howeve, within the context of PA management, the value of local socioeconomic development is primarily instrumental-a tool for achieving the goal of more effective conservation. One consequence of this characteristic of CBC-PA is that those initiating and supporting the projects are likely to focus on environmental implications and underestimate the importance of variables recognized as critical in the field of development.

This section justifies a stronger focus on development variables. The next section addresses questions of definition and measurement. Three of the variables highlighted here-rights, capacity, and governanceare drawn directly from current thinking in international development (United Nations Development Programme 2002). The fourth factor-revenue potential-is included to take into account the special circumstances of villages in the buffer zones of PAs, regions that generally offer limited local economic opportunities beyond small-scale agriculture and animal husbandry.

Evidence from both theory and practice in development suggests that rights, capacity, and governance are critical to success. Sen (1999) provided a theoretical foundation for a focus on these variables by arguing that the essential indicator of human development is the extent to which substantive freedoms are expanded. As Sen defined them, substantive freedoms include not only basic opportunities that derive from access to nutrition, health care, and education but also higher-level benefits that flow from the exercise of social, political, and economic rights. These higher-level rights include, among others, the right to speak openly, own property, and participate in social decision-making. He argued further that, "In this approach, the expansion of freedom is both (1) the primary end and (2) the principal means of development" (Sen 1999, p. 36, emphasis in original).

Following these ideas, multilateral organizations, national aid agencies, and international NGOs operating in developing countries now work to broaden substantive freedoms through expanding rights, enhancing individual and institutional capacity, and improving governance. The United Nations Development Programme (UNDP) and the World Bank both now describe a consensus among practitioners and academics that human development projects cannot succeed without a focus on rights, capacity, and governance (Kaufmann and others 2005; Mizrahi 2004; United Nations Development Programme 2002). As with Sen's substantive freedoms, improvements in rights, capacity, and governance are desirable ends in themselves and also catalysts for further development gains.

More directly relevant to CBC-PA, aid agencies are now applying similar views to understanding and maximizing the development implications of natural resource management. A recent United States Agency for International Development (USAID) discussion paper entitled "Nature, Wealth, and Power" notes the multiple, mutually reinforcing interactions that connect efforts to develop effective environmental management practices, empower rural people, and promote good governance (United States Agency for International Development 2004). Emphasizing links among these variables, the USAID paper argues that capacity is essential for improving natural resource management and that, in turn, effective management of natural resources is central to improving governance and empowering rural people.

The theoretical case for a focus on rights, capacity, and governance, both as they relate to development generally and in the context of natural resource management, is supported by a range of empirical evidence. The World Bank, UNDP, and USAID all report that their current focus on these factors derives from years of practical experience in international development. Researchers examining natural resource management projects on smaller scales have also emphasized the importance of development variables in determining outcomes (Gibson and Marks 1995; Hasler 1999; Nelson 2004).

\section{Definitions of and Interactions Among the Variables}

This section considers problems of defining and measuring rights, capacity, governance, and revenue potential in the context of CBC-PA projects. All four 
variables are complex and incorporate multiple components. Appropriate definitions and indicators remain subject to debate, particularly for capacity and governance. Moreover, whereas multilateral donor agencies and other organizations have studied impacts at the national and international level, the influence of the variables at the local, community level has not been examined systematically (Mizrahi 2004). In the discussion of projects from El Salvador and Zimbabwe presented in the following, I offer qualitative examples of how the impact of these variables might be discerned in particular cases. Quantitative indicators with general applicability are under development but are not yet well established (Kaufmann and others 2005; Mizrahi 2004). Thus, the review of definitions and indicators presented in this section is preliminary and intended to indicate gaps in the knowledge base that need to be addressed as researchers and practitioners focus more closely on these variables in CBC-PA and other community projects.

An indicator for rights in the context of CBC-PA needs to incorporate measures of the presence and strength of various types of formal and traditional rights. Formal rights of concern, generally determined by laws, institutions, and actors outside the community, include the extent to which local residents have legal standing, enforceable property rights, authority for resource management, and protections against arbitrary land-use decisions by state agencies. Important traditional rights, often driven primarily by internal community norms and practices, might include the reliability of usufruct or other forms of customary access to land and resources and the robustness of opportunities to participate in communal resource decision-making.

Moreover, although many observers (Brown 2002; Goldman 2003) have argued that a community-based project cannot succeed if the community does not have authority for project management and if community decision-making processes are not participatory, individual rights are also important. Arguments for devolution of authority to the community level, for example, often implicitly assume that the community is analogous to a benevolent corporate entity. This is obviously an oversimplification (Agrawal and Gibson 1999; Enters and Anderson 1999). Factions and hierarchies that undermine the rights of marginalized subgroups operate even in small, ethnically homogenous villages (Balint and Mashinya 2006). In addition, the success of CBC-PA projects might depend on the entrepreneurship of individual community members, whose rights to act independently might need protection. In addressing the rights variable, practitioners need to both develop quantifiable indicators capturing community and individual rights and implement project components explicitly designed to strengthen these rights.

Capacity refers to the levels of competence, ability, and skills necessary to set and achieve relevant goals. Although references to the importance of capacity are common in development work (Enemark and Ahene 2003; United Nations Development Programme 2002), the notion is complex (Honadle 1981). In a recent review of the literature for the World Bank on capacity building at the national level, Mizrahi (2004, p. 1) wrote that "...little agreement exists about how to define, operationalize, and measure capacity or capacity enhancement." From the point of view of CBC-PA, essential capacity clearly includes relevant technical, managerial, and political skills. Limitations in these areas might be relatively straightforward to identify, although challenging to address. However, capacity also includes intangibles, such as motivation, perseverance, resilience, confidence, optimism, openness to change, and so on. These characteristics are harder both to assess and to strengthen.

As with other variables discussed in this article, capacity needs to be measured and enhanced at various levels. Ultimately capacity resides in people, but research indicates that individual capacities are strengthened or constrained by the organizational and social environments in which people function. Thus, there are feedback loops among individual, organizational, and social capacities. In addition, although there are certainly competencies that have general application, the specific capacities required to achieve goals in CBC-PA projects will vary from case to case. Despite wide agreement on the importance of capacity, development practitioners working at the national level have found it difficult to enhance capacity effectively (Mizrahi 2004). These challenges certainly appear at the community level as well, but if capacity is not addressed, projects are unlikely to be able to sustain any gains that they achieve.

Governance refers to the effectiveness of decisionmaking processes and institutions (Kaufmann and others 2005; Knack 2001). Research to date suggests that this variable is important for CBC-PA because projects are affected by the quality of governance at the community, provincial, and national levels (Roe and others 2000). Where governance is weak at the local level, community participation might be limited and traditional leaders or private firms might expropriate community benefits. At the district and national levels, weak governance structures might allow agencies and officials to usurp a portion of the revenues from local 
conservation activities or otherwise assert their authority at the expense of the community (Balint and Mashinya 2006; Hulme and Murphree 2001).

Over the past decade, governance, like capacity, has become a central focus of development experts. Researchers at the World Bank have measured various dimensions of governance, including transparency and accountability, access to information, rule of law, bureaucratic efficiency, and control of corruption (Kaufmann and others 2005). These broad indicators can be adapted for use in assessing governance relevant for CBC-PA projects. Project managers need to assess and strengthen governance in all participating stakeholder organizations, including local communities, government agencies, and NGOs.

Rights, capacity, and governance are correlated, and researchers and practitioners will face challenges as they work to separate the influences of these related variables. All three, for example, include concepts addressed in social capital research, including the importance of trust and reciprocity (Meinzen-Dick and others 2004; Pretty and Smith 2004). As the variables interact at the national level, improved capacity appears to facilitate more effective governance, and strengthened governance, in turn, tends to promote and expand citizens' rights. Similar interactions seem likely to apply at the community level in improving outcomes in CBC-PA projects.

The fourth variable highlighted in this article relevant for CBC-PA is revenue potential. By revenue potential I refer to the economic value of income-generating opportunities linked to the nearby PA that the community or its members can effectively capture. Not surprisingly, the literature suggests that CBC-PA projects are unlikely to be successful when the economic potential is low relative to the number of households that expect to benefit (Emerton 2001; Muir-Leresche and others 2003). For example, where wild animals of interest to tourists are sparse or hard to see and the population of the local human community is relatively high, revenue from a game-viewing venture is unlikely to sustain a viable project.

Some critics of CBC go further and suggest that as a general rule most community-based tourism projects are oversold and do not have the potential to generate the necessary revenue to meet expectations (Bond 2001; Norton-Griffiths and Southey 1995). Moreover, a leveling tendency has been observed in which communities with relatively high revenue streams attract inmigration, thus reducing per household returns (Noss 1997). As a complication, there is likely to be considerable uncertainty regarding revenue potential at the outset for a given project. The level of income that can be generated, for example, might be contingent on rights, capacity, and governance; that is, as levels of legal authority, competence, experience, and effective leadership increase, the projects will become better able to develop and sustain economically viable activities.

Table 1 presents a summary review of this discussion of the variables. Figure 1 presents a simplified schematic diagram of likely interactions among the four variables and between these variables and the desired conservation and development outcomes. Figure 1 illustrates that rights, capacity, and governance form an interrelated bundle of variables that, as Sen suggested, are both contributors to and consequences of human development. As Figure 1 indicates, improvements in rights, capacity, and governance will reinforce both conservation gains in and around the PA and social and economic gains in the participating communities.

\section{Influence of the Variables in Particular Cases}

To illustrate ways in which these four variables affect outcomes in particular cases, this section reviews CBCPA projects from El Salvador and Zimbabwe. The El Salvador case includes projects in two villages in the buffer zone of El Imposible National Park in the country's western highlands. The Zimbabwe case involves a project in a community near Gonarezhou National Park in the country's southeastern lowveld. I 2 studied the projects in El Salvador during fieldwork conducted from October 1999 to February 2000. With a colleague, I studied the project in Zimbabwe from June to August 2004. Fieldwork in both countries relied on qualitative, ethnographic methods, including review of documents, extended site visits, direct observation, and semistructured and open-ended interviews with community members, NGO and government agency staff, and outside experts. In the El Salvador case, I observed the projects in their early stages. In Zimbabwe, my colleague and I reviewed a project with a 10-year track record to explore whether previously reported gains had been sustained. As detailed reviews of methods and findings are available elsewhere (Balint 2000, 2006; Balint and Mashinya 2006), I do not present full case study reports here; rather, I briefly introduce and describe each case and then discuss the impact on outcomes of the four variables highlighted in this article.

\section{El Salvador}

During land reform programs implemented across El Salvador in the late 1970s, the government acquired two large adjacent haciendas in the isolated and largely 


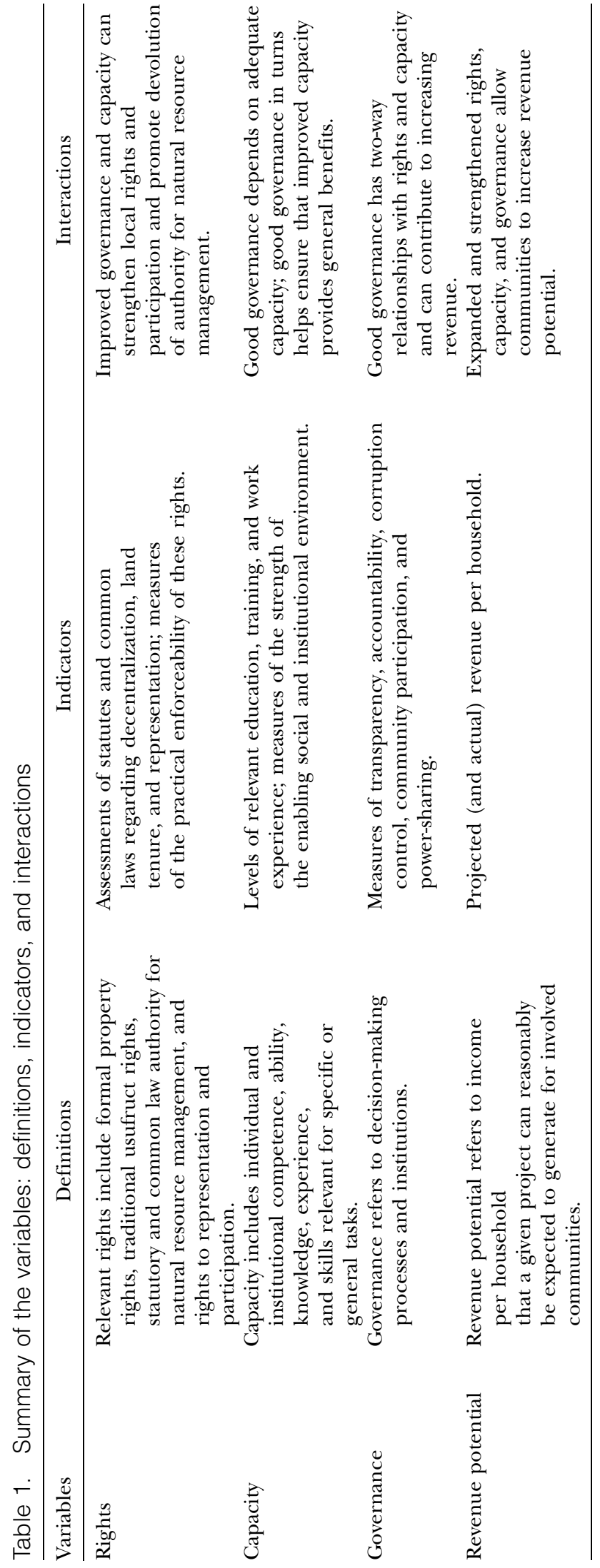

undeveloped western mountains near the Guatemalan border. This forested land known locally as El Imposible, in reference to a treacherous section of the main path down out of the mountains, was set aside as a PA. In 1989, the land was officially designated El Impossible National Park, with management authority vested in the Ministry of Agriculture (Guadrón 1996).

During the civil war of the $1980 \mathrm{~s}$, however, the government had little funding to spare for PA management. Consequently, there was minimal enforcement of new regulations that banned hunting, fishing, and gathering of fuel wood in the park and limited the rights of local residents to clear new land for cultivation in the buffer zone where their villages were located (SalvaNATURA 1997). Then, in 1991 as the conflict neared its conclusion, a Salvadoran environmental NGO based in the capital reached an agreement with the ministry allowing it to assume quasigovernmental authority for park administration. With habitat and biodiversity conservation as its central focus, the NGO began to implement an active management plan that included strict adherence to park and buffer zone regulations.

Not surprisingly, as the NGO asserted its authority, conflicts with locals escalated. By the mid-1990 s, for example, some residents were sabotaging the NGO's work in the park by setting forest fires or dumping agricultural chemicals in streams. There was even talk in several villages of kidnapping the NGO's director to force his organization to temper its hard-line approach. In the second half of the $1990 \mathrm{~s}$, however, the organization, in keeping with changing views of conservationists worldwide, recognized that these continuing conflicts significantly undermined its environmental protection efforts. In a policy change, the NGO began to reach out to neighboring communities. The organization hired new staff with skills and expertise in rural development and over the next several years, it successfully sought funding for various small-scale projects to address local residents' concerns and needs. These projects included installing solar home systems in El Naranjito, an isolated community located along a ridge to the north of the park, and promoting microenterprises linked to ecotourism in San Miguelito, a larger village situated to the south of the park along the main entrance road.

For the El Naranjito project, the NGO installed a solar panel and storage battery in each of the community's 27 households. These solar home systems provided electricity for interior lighting and small appliances. Despite the limitations of these modest systems, community residents were extremely pleased with the improved convenience and quality of life they 


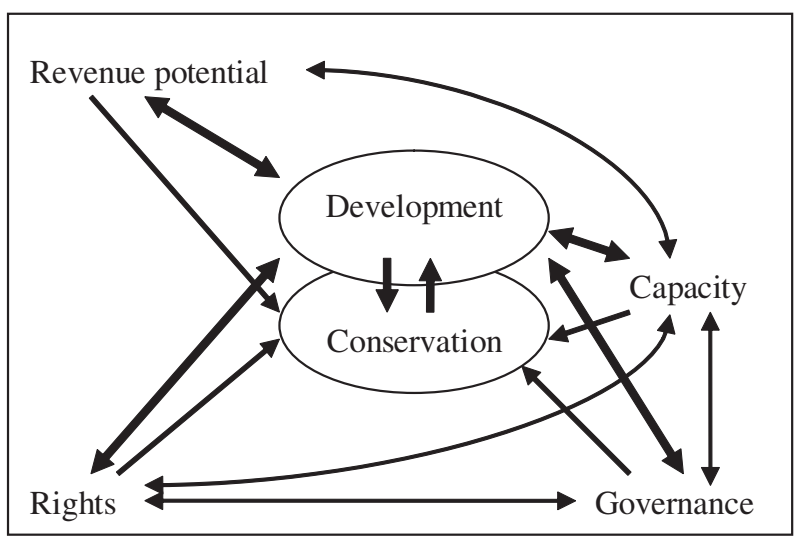

Figure 1. Schematic diagram of interactions among variables.

permitted. Moreover, households could use money previously spent on energy sources for other purposes. In El Naranjito, before installation of the solar systems, families typically spent between $10 \%$ and $15 \%$ of their income on batteries, candles, and kerosene for lamps.

During the period of greatest tension between the NGO and local communities, residents of El Naranjito had been among the most outspoken and antagonistic poachers and saboteurs. With the success of the solar energy project, this hostility and resentment rapidly dissipated. My research documented considerable satisfaction with outcomes and significant changes in attitudes on both sides. NGO staff came to see local residents as partners rather than adversaries, and villagers began to cooperate with park protection efforts. Although my research ended several months after the project was completed, leaving open questions about the long-term sustainability of these improvements, outcomes in the short term were clearly positive.

The second community effort, in San Miguelito, was less successful. This village, located along the road leading to the park entrance, is larger, more developed, less isolated, and less cohesive than El Naranjito. The project in this village attempted to promote microenterprises and employment linked to ecotourism. The NGO hired villagers to help construct a new park visitor center at the San Miguelito entrance, trained locals as guides, and gave small loans to several households in the village to support the establishment of shops and eateries catering to tourists.

Yet tourism in El Imposible is limited. Few foreign visitors come to the park, which by international standards is small and undeveloped, and the flow of domestic tourists-typically small groups of well-to-do Salvadorans from the capital coming in their own vehicles for short camping expeditions or buses of schoolchildren on daytrips-is modest and irregular. These few visitors were insufficient to provide steady work for local residents trained as guides or support shops and restaurants in the village. As their expectations were not realized, community members soon became disillusioned, and signs of resentment and lack of trust resurfaced. For example, locals pilfered building materials from the visitor center construction site, and some villagers who had received small loans to start shops and restaurants absconded with the funds. Animosities also developed between villages as some in San Miguelito complained that residents of El Naranjito had received superior benefits.

The variables discussed in this article-rights, capacity, governance, and revenue-affected project outcomes in the two villages in different ways. In terms of rights, the NGO initially generated intense hostility in both communities by unilaterally overriding traditionally recognized rights and customs. The organization began its work by enforcing previously disregarded regulations that conflicted with long-standing traditional patterns of access to resources in what had become the national park and constrained the land-use practices of smallholders in the buffer zone. Although the NGO had clear legal authority to make these changes, local villagers saw the intervention as a violation of their rights. Thus, at the outset, the NGO struggled at least in part because it both undervalued the customary and legal rights of local people and failed to recognize its own capacity limitations in the area of rural development.

In the solar energy project in the village of $\mathrm{El} \mathrm{Na}$ ranjito, the organization overcame both of these weaknesses. Along with hiring new staff with experience in community development, it brought in outside consultants with expertise in the installation and operation of photovoltaic equipment. Equally important, it implicitly acknowledged villagers' rights by providing a highly desirable quality-of-life improvement to compensate them for agreeing to give up traditional access to resources in the newly protected area and accept land-use restrictions in the buffer zone.

Governance also played a role in El Naranjito. The project was effective in part because community leaders accepted and participated in a village committee with responsibility for overseeing activities and coordinating with residents. Moreover, NGO staff recognized the importance of providing this nascent community governance institution with continuing guidance and support. Higher-level governance issues did not come into play as the ministry had ceded full authority to the $\mathrm{NGO}$, and revenue was not a factor in this case because 
the project did not depend directly on the generation of income for the community from park activities.

Outcomes in San Miguelito illustrated different impacts and interactions involving the variables. In this community, the NGO faced the same initial hostility resulting from perceived usurpation of local rights, but it had less success in overcoming resentments in part because of weaknesses in capacity, community governance, and revenue. In hiring its new staff, the NGO strengthened its capacity to deal with community development, but it did not bring in specific expertise related to promoting microenterprises. Consequently, it could not provide the necessary training and support to prepare new businesses to offer services that tourists might want. Moreover, the NGO did not help develop a market. Tourists visiting this isolated park generally assumed that no local services were available. For the most part, people came with their own supplies and simply drove past the new shops and restaurants. More problematic, the park did not attract enough tourism to meet the expectations of business owners even if all tourists had used local facilities.

Thus, both the NGO and the local start-up businesses it supported lacked essential capacity in business and marketing. Moreover, the park did not have sufficient revenue potential to support the microenterprises or newly trained park guides. Compounding the problem, there were no local governance institutions to ensure that beneficiaries fulfilled their responsibilities. Loan recipients could default on their loans without community censure.

\section{Zimbabwe}

During the 1960s, the government of Rhodesia expropriated a large swath of land in the country's southeast corner to create a game reserve (Wolmer and others 2004). Part of the new PA, later gazetted as Gonarezhou National Park, was cut from the traditional communal territory of the people of Mahenye, who were then resettled across the Save River. Because the colonial regime had by this time asserted ownership of all wildlife, the relocated people were forbidden to hunt either in the park or in their new communal area. Nor were they permitted to kill animals that threatened their lives and crops. Not surprisingly, many turned to poaching. Tensions heightened after 1980, when the government of newly independent Zimbabwe decided not to return the land of the reserve to the former tenants as had been promised during the anticolonial struggle.

At a mediating session convened in 1982 to address the continuing problem of poaching, however, government representatives and community leaders reached an innovative compromise (Murphree 2001; Peterson 1991). Under the plan, the people of Mahenye agreed to cease poaching and to protect wildlife habitat in their territory. In turn, the government allowed the community to contract with a safari operator to organize trophy hunts on its land outside the park, with $80 \%$ of the proceeds from the hunts to benefit local residents. Because the community had no formal standing, the provincial rural district council (RDC) was given legal authority for project management and rights to the remaining $20 \%$ of the income. This arrangement led to considerable conflict over the next several years, as the RDC was consistently slow to pass along the community's share of the revenue (Murphree 2001).

Nevertheless, the approach pioneered in Mahenye demonstrated promise as a way both to promote conservation in and around PAs and to generate revenue for impoverished rural districts. After the concept was developed further by experts from the environment ministry, national NGOs, and the University of Zimbabwe, the government in the late $1980 \mathrm{~s}$ implemented the program nationwide under the banner of CAMPFIRE (Communal Areas Management Programme for Indigenous Resources). During the $1990 \mathrm{~s}$, this program attracted significant support from international donors and was adopted in modified form by various other countries in the region, including Botswana, Namibia, and Zambia.

The Mahenye project was officially integrated into CAMPFIRE in 1991. Up through 2000, it was frequently cited as a model, both for its stable and participatory governing institutions and its diversification of revenue sources (Bond 2001; Matanhire 2003; Murphree 1995). During this period, external reviewers judged the village CAMPFIRE committee to be transparent and accountable, with regular elections, community meetings, and external audits of the project's ledgers (Matanhire 2003; Murphree 2001). Moreover, unlike most CAMPFIRE communities that relied exclusively on revenue from sport hunting, the leaders of the Mahenye project branched out into game-viewing tourism. In 1992, the community and RDC reached agreement with a hotel firm to open two tourist lodges on communal land along the Save River. The company agreed to contribute a percentage of its gross receipts to the project, increasing from $8 \%$ to $12 \%$ over the life of the contract (Murphree 2001). After the lodges opened for business in the mid-1990 s, revenue from lodge receipts and hunting safaris produced annual cash disbursements for each of Mahenye's approximately 800 households, representing an increment of 5-10\% above incomes from subsistence agriculture, animal husbandry, and other sources. In combination 
with job opportunities and infrastructure improvements linked to the lodges, this income provided a significant benefit to the community and its members.

In our research in 2004, however, my colleague and I found that project performance had deteriorated sharply from previously reported conditions. At the time of our study, villagers were receiving annual income from the project of less than US $\$ 1$, community infrastructure improvements had stalled, and leadership institutions were no longer accountable. Community confidence in the project had collapsed, and residents were bitter and disillusioned. The primary problem according to our respondents was that the traditional chief and his family had co-opted project benefits. Prior to 2000, the CAMPFIRE committee and other project management institutions were kept separate from the traditional leadership. In 2000, however, the chief's brother had taken control of the CAMPFIRE committee. Since that time, there had been no elections and the books had not been audited, despite requirements in the bylaws for quarterly audits and biennial elections. According to villagers, all project revenues now benefited only the chief and his family. Perhaps most disturbing, our respondents reported that the new status quo was maintained through threats and intimidation.

Our research points to two factors occurring in 2000 that led to the deterioration of the Mahenye project. First, at this time, major international funding for CAMPFIRE came to an end. As a consequence, the national CAMPFIRE Association and other NGOs reduced their contacts with projects in the field and cut back or eliminated administrative support. Indeed, our interviews with NGO representatives, academics, and government officials in Harare before and after our visit to Mahenye indicated that because of their loss of contact with events on the ground, they were unaware of the project's current problems.

Second, in 2000 the government of Zimbabwe stepped up an aggressive campaign to stay in power that isolated it from the international community, scared away foreign tourists, and undermined the economy, which has since continued to suffer severe inflation and sharply declining gross domestic product (Muir-Leresche and others 2003). Ruling-party tactics have included electoral intimidation and a radical land reform program involving chaotic invasions of white-owned farms and even of national parks and other PAs in some cases (Wolmer and others 2004). Yet although the national crisis contributed directly to a sharp drop in occupancy rates at the Mahenye lodges, we found that the impact of the broader turmoil could not explain the full decline of income going to households from project activities. Instead, our respondents reported that the traditional chief and his family had expropriated the reduced but still significant income that continued to come in from hunting safaris and lodge receipts.

The four variables discussed in this article played significant roles in affecting outcomes in Mahenye. In terms of rights, a common general criticism of CAMPFIRE is that under the program's enabling statutes, devolution of authority for wildlife management stalls at the RDC level (Logan and Moseley 2002; Murombedzi 1999). Results would be substantially better, the argument goes, if rights were fully vested in the communities. Yet, researchers who studied the Mahenye project up through 2000 found that RDC engagement-or interference-had not undermined the project's early success (Matanhire 2003; Murphree 2001), and several of our respondents in the village argued that after 2000 , the RDC was the only remaining check on power of the local elite.

Outcomes in Mahenye suggest that local rights and authority are important but that external checks and balances are also necessary. Under traditions of communal ownership, the chief retains the power to control land-use patterns. Consequently, full devolution of authority to the village level would not have protected individual households from abuse of power by the local elite. Although each family typically has long-standing common-law rights to a particular plot, the lack of secure land tenure at the household level allows the traditional leader to intimidate local opposition with credible threats to rescind these customary rights.

In terms of revenue, although the post-2000 national social and economic crisis severely limited gameviewing tourism, the project still generated sufficient income to maintain its viability. Trophy hunters are less affected by political unrest than ecotourists, and at the time of our research in 2004, the number of hunting safaris in Mahenye had remained stable. In addition, although occupancy rates at the Mahenye lodges were down to $20 \%$ of capacity, the community still received significant income from this source because of contractual language requiring the firm to pay a percentage of gross receipts rather than a percentage of profits. Despite the national crisis, we estimate that if project income had been distributed to households as before, the benefits would still have been at the lower end of the range experienced during the period in which Mahenye was judged a model CAMPFIRE project. In other words, problems other than reduced revenue contributed to the project's sharp decline.

We found that the project deteriorated primarily because of the loss of external capacity and the collapse of local governance. Beginning in 2000, as international funding came to an end, NGOs that had pro- 
vided essential capacity building and administrative support withdrew. At the same time, postindependence improvements in governance at the national and district levels were swept away as the ruling party turned to consolidating its power. In Mahenye, the traditional chief and his family took advantage of these changes to assert control over the local CAMPFIRE committee and co-opt project benefits. Once the chief's brother became committee chair, rules designed to ensure transparency and accountability were ignored and community members' opportunities for participation and redress of grievances were eliminated.

Table 2 summarizes the effects of the four variables in the cases discussed above.

\section{Conclusion}

Protected area management policies often incorporate measures to support economic development in neighboring communities. In principle, communitybased projects improve conditions for local residents, alleviate pressures on reserves, and reduce conflicts between community members and park managers. In practice, however, both conservation and development outcomes often fall below expectations.

Because CBC-PA projects are implemented in association with PA management, the central emphasis is on conservation. Consequently, those involved in developing and supporting community projects might underestimate the importance of lessons learned from experience in international development or lack the expertise to incorporate these lessons effectively. I argue that a clearer focus on development variables, particularly rights, capacity, governance, and revenue, might improve chances for sustainable socioeconomic gains in CBC-PA. This, in turn, will make it more likely that these projects can contribute effectively to conservation objectives.

In this article, I also describe the problem of a lack of clear definitions and standard measures for critical development variables, particularly capacity and governance. The process of social and economic development is poorly understood at the national level, and gaps in the knowledge base are more severe at the community level. A systematic effort to bring development expertise to bear on CBC-PA might improve outcomes in particular projects while helping to identify consistent, quantifiable indicators for these variables.

\section{Acknowledgments}

The College of African Wildlife Management (Mweka) in Tanzania provided support during research

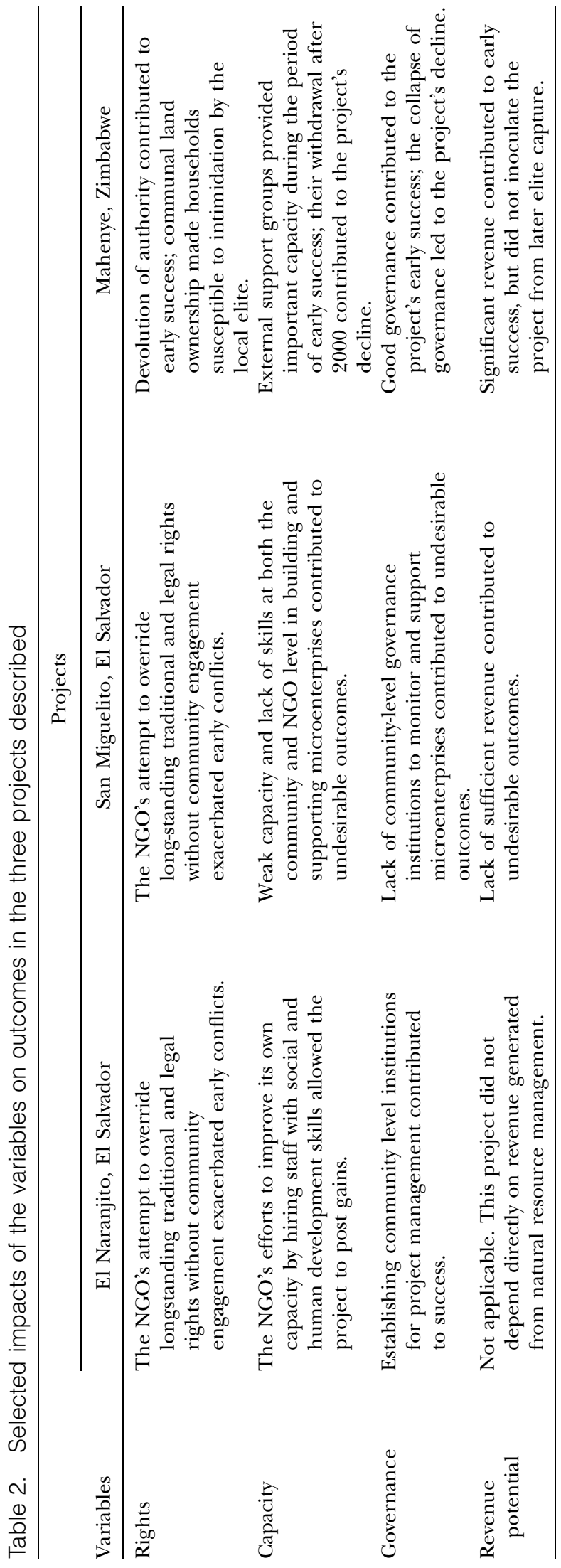


related to the topic addressed in this article. Students and staff at the College offered helpful comments on early drafts. Irina Stoyanova of George Mason University contributed valuable research assistance. I thank Jon Anderson, Steven Bissell, and the editor and reviewers at Environmental Management for insightful and constructive criticism.

\section{Literature Cited}

Agrawal, A. 2001. Common property institutions and sustainable governance of resources. World Development 29:1649-1672.

Agrawal, A., and C. C. Gibson. 1999. Enchantment and disenchantment: the role of community in natural resource conservation. World Development 27:629-649.

Baland, J. M., and J. P. Platteau. 1996. Halting degradation of natural resources: Is there a role for rural communities? Clarendon Press, Oxford, UK.

Balint, P. J. 2000. Balancing conservation and development in rural El Salvador: results from two case studies. PhD dissertation, University of Maryland, College Park, MD.

Balint, P. J. 2006. Bringing solar home systems to rural El

3 Salvador: lessons for small NGOs. Energy Policy (in press).

Balint, P. J., and J. Mashinya. 2006. The decline of a model community-based conservation project: governance, capacity, and devolution in Mahenye, Zimbabwe. Geoforum

4 (in press).

Bond, I. 2001. CAMPFIRE and the incentives for institutional change. Pages 227-243 in D. Hulme, and M. Murphree (eds.), African wildlife and livelihoods: The promise and performance of community conservation. ames Currey, Oxford, UK.

Brandon, K., H. Redford E. and Sanderson(eds.). 1998. Parks in peril: People politics, and protected areas. Island Press, Washington, DC.

Brown, K. 2002. Innovations for conservation and development. The Geographical Journal 168:6-17.

Dietz, T., N. Dolšak, E. Ostrom, and P. C. Stern. 2002. The drama of the commons. Pages 3-35 in E. Ostrom, T. Dietz, N. Dolšak, P. C. Stern, S. Stonich, and E. U. Weber (eds.), The drama of the commons. National Academy Press, Washington, DC.

Emerton, L. 2001. The nature of benefits and the benefits of nature: why wildlife conservation has not economically benefited communities in Africa. Pages 227-243 in D. Hulme, and M. Murphree (eds.), African wildlife and livelihoods: The promise and performance of community conservation. James Currey, Oxford, UK.

Enemark, S., and R. Ahene. 2003. Capacity building in land management: implementing land policy reforms in Malawi. Survey Review 37:20-30.

Enters, T., and J. Anderson. 1999. Rethinking the decentralization and devolution of biodiversity conservation. Unasylva 50:6-11.

Geisler, C. 2002. Endangered humans: how global land conservation efforts are creating a growing class of invisible refugees. Foreign Policy 130:80-81.
Gibson, C., and S. A. Marks. 1995. Transforming rural hunters into conservationists: An assessment of communitybased wildlife management programs in Africa. World Development 23:941-957.

Goldman, M. 2003. Partitioned nature, privileged knowledge: community-based conservation in Tanzania. Development and Change 34:833-862.

Guadrón, J. 1996. Estudio Sociocultural de las comunidades ubicadas en la área de influencia del Parque Nacional El Imposible. USAID, San Salvador, El Salvador.

Hardin, G. 1968. The tragedy of the commons. Science 162: 1243-1248.

Hasler, R. 1999. An overview of the social, ecological and economic achievements and challenges of Zimbabwe's CAMPFIRE Programme. Evaluating Eden Discussion Paper No. 3. International Institute for Environment and Development, London, UK.

Hockings, M. 2003. Systems for assessing the effectiveness of management in protected areas. BioScience 53:823-832.

Honadle, B. 1981. A capacity-building framework: a search for concept and purpose. Public Administration Review 41:575580.

Hulme, D., and M. Murphree (eds.). 2001. African wildlife and livelihoods: The promise and performance of community conservation. James Currey, Oxford, UK.

Kaufmann, D., A. Kraay, and M. Mastruzzi. 2005. Governance matters IV: Governance indicators for 1996-2004. World Bank Institute Working Paper. World Bank, Washington, DC.

Knack, S. 2001. Aid dependence and the quality of governance: cross-country empirical tests. Southern Economic Journal 68:310-329.

Li, T. M. 2002. Engaging simplifications: community-based resource management, market resources and state agendas in upland Southeast Asia. World Development 30:265-283.

Logan, B. I., and W. G. Moseley. 2002. The political ecology of poverty alleviation in Zimbabwe's Communal Areas Management Programme for Indigenous Resources (CAMPFIRE). Geoforum 33:1-14.

Matanhire, S. 2003. Process Oriented Monitoring System (POMS) evaluation of select sub-district CAMPFIRE institutions. Zimbabwe Trust for WWF-SARPO, Harare, Zimbabwe.

Meinzen-Dick, R., M. DiGregorio, and N. McCarthy. 2004. Methods for studying collective action in rural development. Agricultural Systems 82:197-214.

Mizrahi, Y. 2004. Capacity enhancement indicators: Review of the literature. World Bank Institute Working Paper 37232. World Bank, Washington, DC.

Muir-Leresche, K., I. Bond, W. Chambati, and A. Khumalo. 2003. An analysis of CAMPFIRE revenue generation and distribution: The first decade (1989-2000). WWF-SARPO, Harare, Zimbabwe.

Murombedzi, J. 1999. Devolution and stewardship in Zimbabwe's CAMPFIRE programme. Journal of International Development 11:287-293.

Murphree, M. 1995. The lesson from Mahenye: Rural poverty, democracy and wildlife conservation. Wildlife and Devel- 
opment Series No. 1. International Institute for Environment and Development, London, UK

Murphree, M. 2001. Community, council and client: A case study in ecotourism development from Mahenye, Zimbabwe. Pages 177-194 in D. Hulme, and M. Murphree (eds.), African wildlife and livelihoods: The promise and performance of community conservation. ames Currey, Oxford, UK.

Nelson, F. 2004. The evolution and impacts of communitybased ecotourism in northern Tanzania. IIED Drylands Issue Paper No. 131. International Institute for Environment and Development, London, UK.

Neumann, R. 1998. Imposing wilderness: Struggles over livelihood and nature preservation in Africa. University of California Press, Berkeley.

Neumann, R. 2004. Moral and discursive geographies in the war for biodiversity in Africa. Political Geography 23:813-837.

Norton-Griffiths, M., and C. Southey. 1995. The opportunity costs of biodiversity conservation in Kenya. Ecological Economics 12:125-139.

Noss, A. J. 1997. Challenges to nature conservation with community development in central African forests. Oryx 31:180-188.

Ostrom, E. 1990. Governing the commons: the evolution of institutions for collective action. Cambridge University Press, New York.

Ostrom, E., T. Dietz, N. Dolšak, P. C. Stern, S. Stonich, and E. U. Weber (eds.). 2002. The drama of the commons. National Academy Press, Washington, DC.

Packer, C., D. Ikanda, B. Kissui, and H. Kushnir. 2005. Lion attacks on humans in Tanzania. Nature 436:927-928.

Peterson, J. H. 1991. A proto-CAMPFIRE initiative in Mahenye Ward, Chipinge District: Development of a wildlife programme in response to community needs. Centre for Applied Social Sciences, University of Zimbabwe, Harare.

Pretty, J., and D. Smith. 2004. Social capital in biodiversity conservation and management. Conservation Biology 18:631638.

Roe, D., and M. Jack, (eds.). 2001. Stories from Eden: Studies of community-based wildlife management. Evaluating Eden
Series No. 9. International Institute for Environment and Development, London, UK.

Roe, D., J. Mayers, M. Greig-Gran, A. Kothari, and R. Hughes (eds.). 2000. Evaluating Eden: Exploring the myths and realities of community-based wildlife management. Evaluating Eden Series No. 8. International Institute for Environment and Development, London, UK.

SalvaNATURA, 1997. Plan general de Manejo y Desarrollo para el Parque Nacional El Imposible. SalvaNATURA, San Salvador, El Salvador.

Sen, A. 1999. Development as freedom. Knopf, New York.

Songorwa, A. N. 1999. Community-based wildlife management $(\mathrm{CWM})$ in Tanzania: Are the communities interested? World Development 27:2061-2079.

Stern, P. C., T. Dietz, N. Dolšak, E. Ostrom, and S. Stonich. 2002. Knowledge and questions after 15 years of research. Pages 445-486 in E. Ostrom, T. Dietz, N. Dolšak, P. C. Stern, S. Stonich, and E. U. Weber (eds.), The drama of the commons. National Academy Press, Washington, DC.

Twyman, C. 2000. Participatory conservation? Communitybased natural resource management in Botswana. The Geographical Journal 166:323-335.

United Nations Development Programme. 2002. Human development report 2002: Deepening democracy in a fragmented world. Oxford University Press, New York.

United States Agency for International Development. 2004. Nature, wealth, and power. USAID, Washington, DC.

Wade, R. 1988. Village republics: economic conditions for collective action in South India. ICS Press, Oakland.

Western, D., and R. M. Wright, (eds.). 1994. Natural connections: perspectives in community-based conservation. Island Press, Washington, DC.

Wolmer, W., J. Chaumba, and I. Scoones. 2004. Wildlife management and land reform in southeastern Zimbabwe: A compatible pairing or a contradiction in terms? Geoforum 35:87-98 


\section{Author Query Form}

Journal : EM

Article No. : 0100y

Disk Usage : $\square$ Yes $\square$ No

Incompatible file format $\quad \square \quad$ Virus infected

Discrepancies between electronic file and hard copy

Other:

Manuscript keyed in

$\square \quad$ Files partly used (parts keyboarded.)

Author Queries

\begin{tabular}{|l|l|l|}
\hline Sr. No. & Query & Author's Remarks \\
\hline 1 & NGO $=$ nongovernment organization? & \\
\hline 2 & Lowveld or low veld? Please check. & \\
\hline 3 & Please provide volume \# and issue \#. & \\
\hline 4 & Please provide volume \# and page \#. & \\
\hline 5 & Provide location of publisher. & \\
\hline
\end{tabular}

